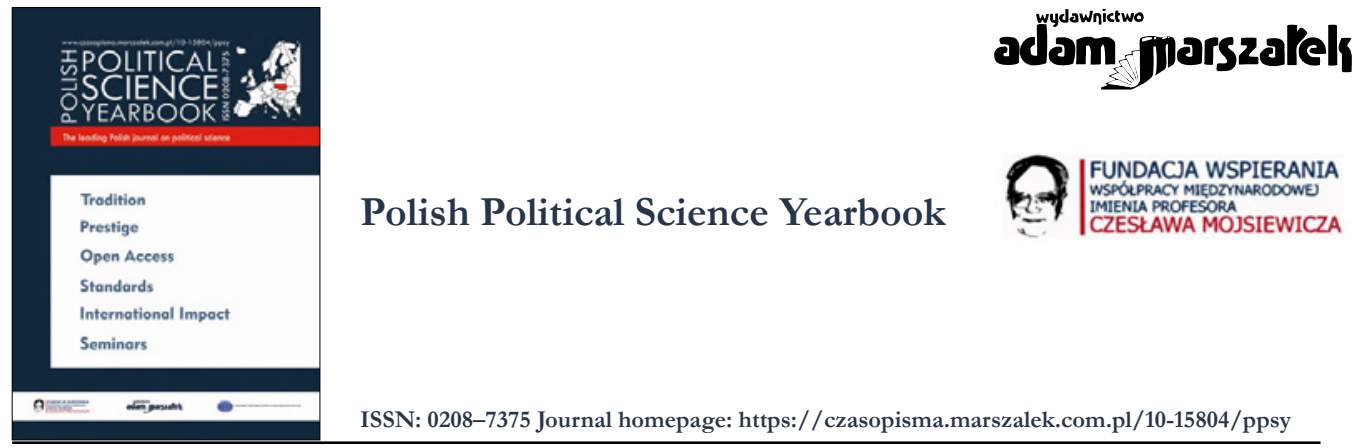

\title{
Impact of the COVID-19 Pandemic on the Relations Between Government and Parliamentary Opposition in Spain
}

\section{Agata Rydzewska}

ORCID: 0000-0001-7772-4275

To cite this article please include the following information:

- Journal title: Polish Political Science Yearbook

- Volume number: 50

- Year of publication: 2021

- Published ahead-of-print

Example styles:

[APA Style]: Rydzewska, A. (2021). Impact of the COVID-19 Pandemic on the Relations Between Government and Parliamentary Opposition in Spain. Polish Political Science Yearbook, 50 (issue number), pages. https://doi.org/10.15804/ppsy202130

[Chicago Style]: Agata Rydzewska, "Impact of the COVID-19 Pandemic on the Relations Between Government and Parliamentary Opposition in Spain" Polish Political Science Yearbook 50, no. [issue number] (2021).

To link to this article: https://doi.org/10.15804/ppsy202130

Published ahead-of-print

Final submission: 30 June 2021

Published online: 7 July 2021

Printed issue: December 2021

Submit your article to PPSY 


\title{
Agata Rydzewska
}

University of Warsaw (Poland)

ORCID: 0000-0001-7772-4275

e-mail: a.rydzewska14@student.uw.edu.pl

\section{Impact of the COVID-19 Pandemic on the Relations Between Government and Parliamentary Opposition in Spain}

\begin{abstract}
The COVID-19 strongly affected the states all over the world in several aspects, Spain, being an inglorious leader in terms of the number of infections in Europe, was highly afflicted by the coronavirus and further consequences. After problems with forming the government, which was caused by substantial political polarization, a new incumbent coalition needed to face new challenges, which was strictly connected with managing the coronavirus crisis. The article's main aim is to present how the COVID-19 pandemic impacted the political situation in Spain by analyzing the relations between the ruling government and the parliamentary opposition.
\end{abstract}

Keywords: Spanish politics, COVID-19, coronavirus crisis, pandemic in Spain, government-opposition relations

\section{Introduction}

Spain was one of the states strongly affected by the first wave of the coronavirus ${ }^{1}$. Not only has this state been an inglorious leader in terms of COVID-19 cases among members of the European Union, but it also has been struggling with the highest number of infections among medical personnel. Furthermore, the daily number of deaths caused by the coronavirus remained above 400 from March 22 to April 22, 2020. As the pandemic has been evolving, the Spanish authorities were criticized for responding too late and taking inappropriate actions. The severe crisis caused by the first wave of the COVID-19 epidemic has impacted

${ }^{1}$ Due to the needs of the article, it is required to assume that the first wave of COVID-19 occurred from March 2020 to June 2020 within the end of state of alarm in Spain. 
the state's political situation and led to tensions and conflicts. The article aims to analyze the relationship between the government and parliamentary opposition in terms of the model of the opposition's behavior and to check whether the 'rally around the flag' mechanism in an adapted form has worked out here.

\section{Theoretical Framework and Hypotheses}

In the beginning, it is worth mentioning the theoretical framework of the government opposition coexistence. Several articles and publications raise the issue of the relations between ruling government, both one-party and coalition, with parliamentary opposition (Dahl, 1965; Katz \& Maier, 1995; Łabędź, 2012; Andeweg, 2013; Pastuszko, 2018). The shape of the parliamentary behavior primarily depends on the system of the institutions, the government's type, and the polarization. The studies about the theory of the relations between government and parliamentary opposition distinguish mainly two options of voting behavior. On the one hand, there is an adversarial model based on the conflict. On the other hand, there is a consensual model based on the attempts to reach agreements and cooperation. The opposition that decides to behave according with the first option is concentrated on "emphasising disagreements and confrontation in order to weaken the incumbent government and to gain office" (Palau et al., 2015, p. 77). In the consensual model, parties can cooperate, especially in the most relevant issues in terms of the policy decision-making process. Opposition parties often agree with the government or attempt to find a consensus and are unlikely to constantly reject the government's proposals (Palau et al., 2015). Generally, opposition parties need to face two kinds of pressure from different directions. First, the will of competition, often leading to conflict, which helps to differentiate from the incumbent government and its decisions. Second, the need for cooperation that will impact the current political, economic, or social issues (Guasti \& Zdenka, 2016).

From the perspective of government-opposition relations, it is worth mentioning the potential impact of majority and minority governments on their dynamics. The majority government tends to control all of the political agenda. Its role often takes the form of the so-called "legislative dictator" (Xis \& Noury, 2016, p. 254). In contrast, there is a minority government that is forced to search for approval among the opposition parties and create coalitions when necessary. In this case, the importance of the opposition is much higher, as it is impossible to pass the bill without their support (Xis \& Noury, 2016).

Additionally, the relations between the incumbent government and the opposition may also be influenced by various crises. Few works pay attention to the behavior of the opposition during the crisis. However, it mostly advocates for the statement that crisis is somehow responsible for stronger polarization of the political landscape. It also tends to cause more conflicts than consensus in government-opposition relations (De Giorgi \& Moury, 2015). Furthermore, the COVID-19 crisis shares some similarities with the military crisis, as daily life was hugely affected by it, and the origin of the crisis was external. Therefore, it could be 
considered from the perspective of the rally around the flag, both in terms of parliamentary opposition and public opinion (Jenny \& Muller, 2020). The crisis and its consequences tend to boost the feeling of belonging to the nation, leading to a more supportive approach to the government and other political institutions (Mueller, 1973).

This paper aims to analyze the impact of the COVID-19 crisis on the relations between government and parliamentary opposition. Based on the literature review and theoretical framework, four hypotheses were set for verification:

H1: The rally around the flag rule was followed by the Spanish parliamentary opposition at the beginning of the crisis.

H2: The dominant model of opposition is mostly adversarial.

$\mathrm{H} 3$ : The longer the crisis existed, the more demanding it was for the ruling coalition to gain support from the opposition parties.

H4: The public opinion expressed its sentiment toward the incumbent government following the rally around the flag logic.

The Polish, English, and Spanish sources used to verify hypotheses are primary (document bases) and secondary (press articles, scientific publications). The variety of materials allows following the steps taken by the government to minimalize the negative effects of the COVID-19 crisis, the reactions of the opposition toward these decisions, and the public opinion during the development of the pandemic. Furthermore, the description of the situation before the pandemic outbreak helps explain the impact of the crisis on the political landscape during the first wave of coronavirus.

\section{The Dynamics of the Spanish Politics Before the COVID-19 Outbreak}

To start reflecting on the impact of coronavirus on the political situation in Spain and the relations between the central government and parliamentary opposition, it is considered necessary to elucidate its condition before the pandemic. Till the parliamentary election in Spain in 2015, the Spanish party system had been classified as the two-party system. The main parties' total vote share used to vary between 65 to $84 \%$ in 1989-2008 period, however as a consequence of the crisis in 2008, this advantage over the other smaller parties has come to an end (Orriols \& Cordero, 2016).

The deep economic recession caused social discontent, which was shown, for example, during the public protests called the ' $15-\mathrm{M}^{\prime}$ movement ${ }^{2}$. Furthermore, the citizens' dissatis-

2 The public protest that took place in May 15, 2011, in which participated the thousands of Spanish citizens in order to express their dissatisfaction with the social, political and economic situation in the state. The main slogan of the movement was "Real Democracy Now" («Democracia Real Ya»). What is crucial about this movement is that it had not been organized without the usage of new Information and Communications Technology. Furthermore, right after the protest occurred, the new parties e.g. Podemos appeared (Casas, Davesa, and Congosto, 2016). 
faction was also escalated by corruption cases within the public institutions or the ruling party, the People's Party (Partido Popular, PP). That is why the political campaign before the general elections in 2015 was not easy for the PP. Moreover, it was not an effortless task for the second biggest party - the Spanish Socialist Workers' Party (Partido Socialista Obrero Español, PSOE). The discourse of the '15-M' movement was based on the message that PP and PSOE were responsible for the crisis and all of the so-called "old" parties "are thieves", and they should have paid equally for their mistakes. The new parties created after the protest, made a lot of effort to present PP and PSOE as something the same, using phrases such as "PPSOE" or "It is not about left or right, but about new and old" (López, 2018).

Even though the polls showed that PP would gain the highest number of seats, it was already known that the difficulties with forming the government would appear. The Spanish general election that was held in 2015 resulted in a breakdown of the traditional twoparty system. The PP and PSOE shared only $50.7 \%$ of the total vote share. The number of seats gained by Podemos and Ciudadanos impacted the dynamics of Spanish politics. The parliament was fragmented for the first time since 1982, and no one managed to obtain the majority. The parliamentary arithmetic and the lack of support for Pedro Sánchez, leader of PSOE, resulted in dissolving the Congress of Deputies and the Senate by King Felipe VI and the announcement of a new general election (Orriols \& Cordero, 2016).

From this time, the incapacity of formation of the government has happened two times during only four years. This phenomenon reveals the level of polarization of Spanish politics. The last general election was also held because of the inability to form the government (Minder, 2019). Finally, in January 2020, Pedro Sánchez won the investiture vote by 167 votes to 165 and became the prime minister for the second time in a row. However, it was an unprecedented situation in the contemporary history of Spain because it was a coalition government consisted of the member of PSOE, Unidas Podemos ${ }^{3}$, and independents (Jones, 2020a). Despite the successful forming of the government, the mutual number of seats of the coalition members was not sufficient to have an absolute majority, which means that the government formed in January was a minority one (Caprio, 2020).

\section{The Impact of Coronacrisis on the Government - Opposition Relations}

The first case of coronavirus in Spain was registered at the end of January. In the beginning, the central government did not take any determined actions, the recommendations and the pieces of advice were the basis of the taken steps, and it was rather the autonomous communities in charge of managing the increasing number of infections and deaths due to COVID-19. The central government's message was that the coronavirus would not significantly influence Spain (Jiménez, 2020). The decisions that were applied nationally were

3 Unidas Podemos - a coalition between Podemos, Izquierda Unida and CatComú (Manetto \& Gracía de Blas, 2016). 
taken in the half of March, starting with banning direct flight from Italy, prohibiting the gatherings of more than 1,000 participants in some areas, and closing the schools. Additionally, the first municipalities were placed on lockdown (Pinedo et al., 2020).

One of the most controversial events from the political and social perspectives occurred on March 7-8. At that time, several kinds of events occurred - sports, cultural, and political ones, such as the Women's Day demonstration or a Vox party rally. Not only did the government prohibit the gatherings, but it also encourages to participate in the "8M Manifestation". This weekend was the "last normal one" in the state as only a few days later, on March 14, the state of alarm ${ }^{4}$ was announced (Jiménez, 2020).

The announcement and attempts of further extensions of the state of alarm triggered the conflicts and tensions between the ruling coalition and the opposition. In the case of establishing the state of the emergency due to COVID-19 for the first time, main opposition parties supported the solution. However, they criticized the central government for the late response. Pablo Casado, president of PP, considered as the leader of the whole opposition, because he leads the party with the highest number of seats in the Congress of Deputies among opposition parties, pointed out that actions had been taken too late and that the government had not paid enough attention to the, e.g., economic issues (Ángel, 2020). Despite criticism, political parties agreed with steps taken by the central government. Therefore, the parliamentary behavior could be classified as a consensual model.

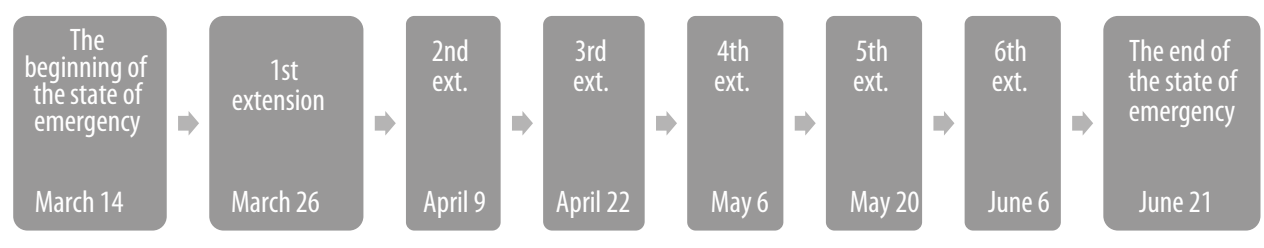

Scheme 1. The announcement and further extensions of the state of alarm in Spain

Source: Own elaboration based on La Moncloa. Estado de Alarma, https:/www.lamoncloa.gob.es/covid-19/ Paginas/estado-de-alarma.aspx

Despite support for the announcement of the state of alarm, the opposition, mainly PP, did not cease to criticize the government's decisions and actions. The core of the discourse was the insufficient number of sanitary materials. Teodoro García Egea, the SecretaryGeneral of PP, accused the prime minister of being responsible for wrong management during the crisis (Lamet, 2020). Not only did PP demand from the government to centralize

4 According to the Spanish Constitution "A state of alarm shall be declared by the Government, by means of a decree decided upon by the Council of Ministers, for a maximum period of fifteen days. The Congress of Deputies shall be informed and must meet immediately for this purpose. Without their authorization the said period my not be extended. The decree shall specify the territorial area to which the effects of the proclamation shall apply" (The Spanish Constitution, 1978). 
the orders of respirators, masks, and other necessary equipment, but also to start massive testing (Lamet, 2020a).

On March 26, the voting about the first extension of the state of alarm took place. Similar to the voting about establishing the state of emergency, it was supported by opposition parties, except the independentist parties. However, the parliamentary discussion was not without difficulties. On the contrary, it was full of criticism toward Pedro Sánchez. On the one hand, there was opposition pointing out the mistakes. For example, Pablo Casado mentioned the manifestation that took place on March 8, accusing the government of allowing for organizing it. Moreover, the leader of the far-right political party Vox, Santiago Abascal, charged the ruling coalition with lying to citizens and seizing an opportunity to use the power. On the other hand, the Spanish prime minister attempted to defend his government and ask for solidarity invoking the relation between the ruling party and opposition in Portugal, the United Kingdom, or France (Cruz, 2020).

While the pandemic was evolving, the discussion in the Spanish parliament was becoming more and more animated. Even though the minority government managed to achieve the required majority to prolong the state of alarm for the second time, it was not supported as much as before (312 votes in favor, 0 against, and 28 abstentions). The block of opposition stopped voting in the same way. For instance, 52 members of the far-right party Vox and two politicians from CUP voted against it (Garea, 2020). The reason for disapproval of the next extension by Vox was the opinion that the government did not have an appropriate plan for the crisis. Santiago Abascal considered Pablo Sánchez responsible for the "world's highest rate of deaths due to COVID-19" (Estaban, 2020). The downward trend in support of prolonging the state of emergency was continuing. In the case of the third extension, the number of votes in favor decrease to 269 . That time, like during the previous voting, the ruling coalition could not obtain approval of Vox and CUP. Once again Spanish prime minister was criticized for being, in the opinion of, e.g., Pablo Casado, incompetent to find a measure to overcome the crisis. Furthermore, the leader of PP also reminded that the government had taken the actions against coronavirus and its consequences with the unacceptable delay (Mayor, 2020).

The conflict between the government and the opposition was deepening. As a result, when it came to prolong the state of alarm for the fourth time at the end of April, PP, the most numerous opposition party, decided to abstain from voting. Pablo Casado pointed out the mistakes of the ruling coalition. Firstly, according to PP, the wrong actions were taken regarding ordering tests and sanitary materials. Secondly, while announcing his disapproval of the next extension, Pablo Casado highlighted that his party could not support Pedro Sánchez's proposal also because of the lack of reactivation of the economy as it was required. However, the prolonging was still supported by Ciudadanos and The Basque Nationalist Party (PNV, Partido Nacionalista Vasco), which was enough to gain the majority (Carreño, 2020). It was passed with 178 votes in favor, 75 against, and 97 abstentions (Carreño \& Pinedo, 2020). 
The Spanish prime minister convinced Ciudadanos, PNV, and other smaller parliamentary groups to vote in favor of the fifth extension. In 350-seat Congress, 177 members voted for the prolonging; however, there were significantly more votes against than before - 162 (Gil, 2020a). Moreover, to secure the majority of votes, the government signed an agreement with EH Bildu, a left-wing party connected with the Basque separatist movement. What makes it more controversial is that by several Spaniards, it is considered the heir of ETA. Kept in secret till the last moment agreement caused new tensions in Spanish politics. The sides agreed for the EH Bildu's abstention during the voting in exchange for full repeal of the labor reform, which PP had introduced in 2012. Nevertheless, after voting, PSOE publishes the note clarifying the pact, which meant changing its first point meaning and returning to the undefined phrase about recovering the labor rights taken away before. What is more, it turned out that the agreement with EH Bild was not needed as even with their votes against it, it would be possible to pass the extension. Such a decision gave the opposition more reason to criticize the ruling coalition (Diez \& Gómez, 2020).

The growing opposition toward further extensions and criticism of the government's crisis management reached its peak when Pedro Sánchez attempted to prolong the state of alarm for the last time. For instance, Pablo Casado called the Spanish prime minister a "prisoner of his supporters", mentioned his will to promote the idea of creating the commission that will analyze the governance during the pandemic, and accused him of being the least democratic in Spanish democracy. Additionally, Santiago Abascal returned to the " $8 \mathrm{M}$ Manifestation" as a response to Sánchez's speech when the prime minister tried to defend the celebration of Women's Day. Leader of Vox charged the government with thousands of deaths due to COVID-19 and made a strong comparison that "Long live March 8" ("Viva el 8 de marzo") in that case meant "Long live the illness and long live the death" ("Viva la enfermedad y viva la muerte"). Anyway, the last extension has been passed and lasted till June 21 (Gil, 2020b).

It is required to highlight that there was little dialogue and cooperation in the Spanish parliament and the whole relation of the government and the opposition. On the one hand, Pedro Sánchez, in the spring peak of infection in Spain, did not pay enough attention to debating and consulting with the opposition to further fight with coronavirus. He called for solidarity. However, he did not make enough effort to keep the dialogue and good relations with most of the opposition. On the other hand, there was PP and Vox, which in the very beginning supported the actions, but later rejected to vote in favor of further extensions of the state of alarm while criticizing the ruling coalition, e.g., for incompetence and inclination toward the totalitarian regime. The relations between the government and the opposition were full of tensions and criticism toward one another. Spain, together with Italy, was one of the exceptions among states of Western Europe. For instance, in Germany, Austria, or the Netherlands, the parliamentary behavior could be described by a consensual model. The political debate was based on the idea of consensus and coalition. In the case of Spain, political parties tended to emphasize differences and point out mistakes to weaken the 
incumbent government. There was constant political conflict, which reveals the level of polarization (Jones, 2020b).

\section{The Public Opinion About Parliamentary Tensions}

Regarding the changes in public opinion, it is worth considering the polls from March 2020, when there was the first establishment of the state of alarm, till the last one, which was ended in June 2020. The graph below is based on the four polls conducted by the Center for Sociological Research (Centro de Investigaciones Sociológicas, CIS) on March 1-13, March 30 - April 7, May 4-13, and June 1-9.

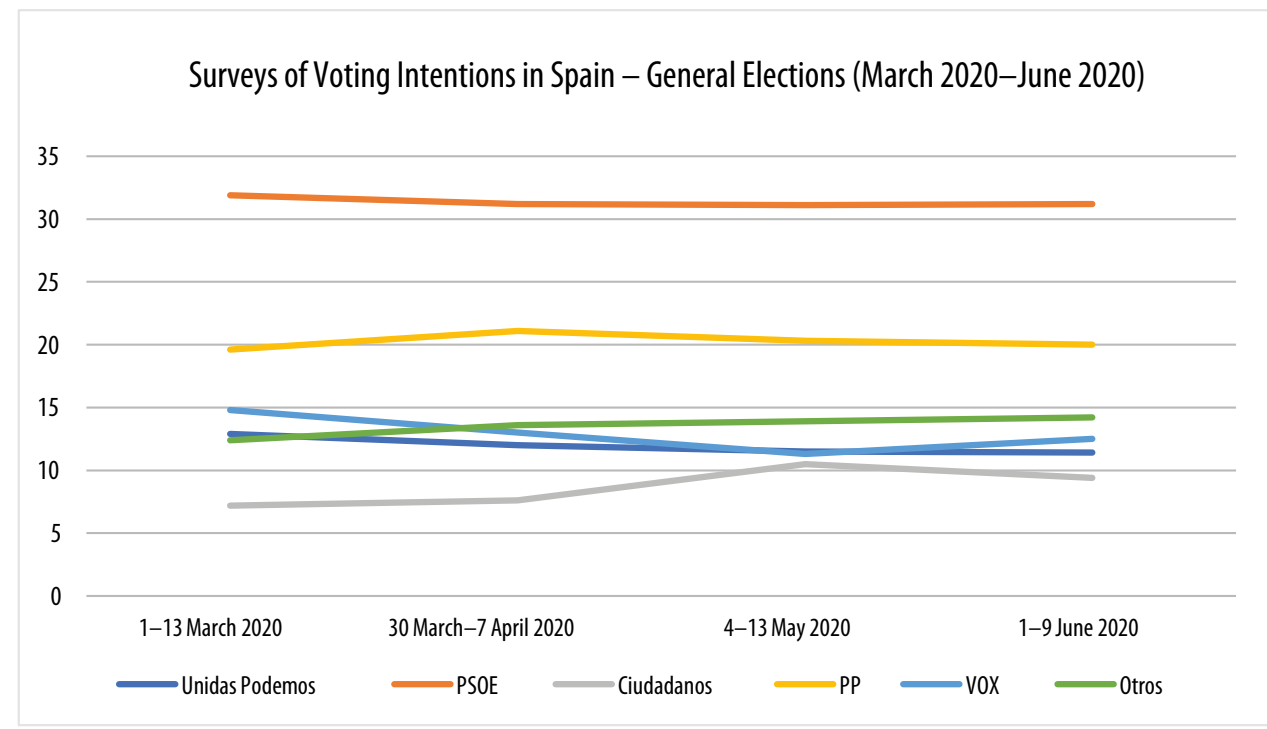

Graph 1. The surveys of voting intentions in general elections in Spain (March 2020-June 2020)

Source: Own elaboration based on surveys conducted by the Centre for Sociological Research, https:// elelectoral.com/encuesta-media/

Surveys do not present any significant changes in support due to the first wave of the coronavirus and the restrictions set to minimalize its effects. In general, the voting intentions remained rather stable. However, what can be noticed is that the party from the coalition which lost the most was Unidas Podemos. Compared to PSOE, Unidas Podemos in the analyzed period lost 1,5 points, while PSOE only 0 ,7. In the case of PP, there was a 1,5-point rise at the beginning of April, although the support decreased again and returned to be on a similar level as in March. Furthermore, there were slight changes in support of Ciudadanos $(+2,2)$ and $\operatorname{VOX}(-2,3)$. 
Even though the surveys of the voting intentions do not indicate any increases or decreases in terms of support for the ruling coalition or parliamentary opposition, the results of different studies of CIS, conducted in April, showed that $87,8 \%$ of respondents answered that opposition parties should support and cooperate with incumbent government (Marcos, 2020a). A similar survey conducted in May indicated that $75 \%$ of respondents believe that the opposition should cease criticizing the government (Marcos, 2020b). Despite the great decrease, it is still possible to notice that the majority preferred the opposition to collaborate with the incumbent government and was skeptical toward the permanent criticism of the ruling coalition.

\section{Conclusions}

The first wave of the COVID-19 pandemic strongly affected Spain and its political situation. The main problems were one of the highest rates of death and infections in Europe, also among medical personnel, late response to the crisis, which was also noticed by other states, and rapidly worsening economic situation that had not been in good condition even before the coronavirus crisis. All of these aspects had to impact on the relations between government and parliamentary opposition. Before the crisis, huge political polarization had already been noticed, which resulted in difficulties with forming the government.

The first hypothesis concerned the rally around the flag rule. As it was hypothesized, at the very beginning, the parliamentary opposition, despite the criticism toward the government for the late response, agreed to the establishment of the state of alarm. However, this party-wide agreement does not last long. The first prolonging of the restrictions was not supported by independentist parties, although the main oppositionists voted in favor. Nonetheless, a growing number of voices pointed out the incumbent government's mistakes, which shows an attempt to cooperate and act according to rally around the flag logic, but it was not long-lasting.

The second hypothesis was about the dominant model of opposition behavior that occurred to be adversarial, which means that it was based more on conflict and focused on emphasizing disagreements and confrontations. Despite voting in favor of a state of alarm and few extensions, the opposition parties constantly underlined the mistakes, accused of incompetence and inclination toward the totalitarian regime, and used strong rhetoric to weaken the incumbent government. However, the model of behavior was adopted not only because of distinguished ideas of COVID-19 crisis management but also of the increasingly polarized Spanish party system.

The third hypothesis assumed that while pandemic was evolving, it became more and more demanding for the government to gain the required majority to extend the state of the alarm. From one voting to another, it was more difficult to convince the parliament members to vote in favor. It was noticeable from the first time when the government decided to prolong the state of alarm established in March. The downward trend in support of 
prolonging the state of emergency was continuing. With deepening conflict and tensions between the government and parliamentary opposition, fewer votes favored the extensions. Finally, even the biggest opposition party announced their disapproval of the next prolonging. In the case of the fifth extension, even though the law was passed, however, there were significantly more votes against than before -162 . The peak of growing opposition toward further extensions and criticism of the government's crisis management was reached when there was an attempt to extend the state of alarm for the last time.

Regarding public opinion, there were only slight changes in voting intentions during the first wave of the pandemic. Although there was not an impressive increase of support for the ruling coalition, most respondents were against the criticism made toward the incumbent government. It may prove that rally around the flag logic, during the crisis of external origin, to some extent has worked out.

In conclusion, the coronavirus crisis influenced relations between government and parliamentary opposition. It caused several problems which ensued from the political polarization and lack of preparation for crisis tools of effective cooperation and coordination. The first wave of the coronavirus pandemic crisis revealed that even in difficult times, it is not an easy task to find solidarity with the polarized political landscape. However, to some degree, rally around the flag mechanism worked out, in the beginning also in parliamentary opposition.

\section{References:}

Andeweg, B. (2013). Parties in Parliament: The Blurring of Opposition. In W.C. Mueller \& H.M. Narud (Eds.), Party Governance and Party Democracy (pp. 99-114). Springer.

Caprio, J. (2020, January 7). PSOE y Unidas Podemos ponen en marcha el primer gobierno de coalición en la historia reciente de España. RTVE. https://www.rtve.es/noticias/20200107/psoe-unidas-podemosponen-marcha-primer-gobierno-coalicion-historia-reciente-espana/1994920.shtml

Carreño, B. (2020, May 6). Spanish leader looks set to secure extension to state of emergency. Reuters. https:// www.reuters.com/article/idUSL8N2CN7BR

Carreño, B., \& Pinedo, E. (2020, May 6). Spain extends state of emergency after PM musters opposition support. Reuters. https://www.reuters.com/article/idUSKBN22I16C

Cruz, M. (2020, March 26). El Congreso apoya el estado de alarma entre críticas a la gestión de Pedro Sánchez del coronavirus: "Esto no va bien, no está a la altura". El Mundo. https://www.elmundo.es/espana/20 20/03/25/5e7bdfc4fc6c83bc2e8b4670.html

Dahl, R. (1965). Reflections on Opposition in Western Democracies. Government and Opposition, 1(1), 7-24.

De Giorgi, E., \& Moury, C. (2015). Conclusion: Great Recession, Great Cooperation? The Journal of Legislative Studies, 21(1), 115-120.

Diez, A., \& Gómez, M. (2020, May 21). El PSOE rectifica el pacto con Bildu y no derogará integramente la reforma laboral. El País. https://elpais.com/economia/2020-05-21/el-psoe-rectifica-el-pacto-con-bilduy-no-derogara-integramente-la-reforma-laboral.html

Estaban, P. (2020, April 9). Vox no apoya la prórroga: "Han conseguido la mayor tasa de mortalidad del 
mundo. El Confidencial. https://www.elconfidencial.com/espana/2020-04-09/vox-no-apoya-prorrogatasa-mortalidad-mundo_2541800/

Garea, F. (2020,April 9). Sánchez pide un pacto a un Congreso cada vez más dividido y crítico. El Confidencial. https://www.elconfidencial.com/espana/2020-04-09/sanchez-pide-un-pacto-a-un-congreso-cadavez-mas-dividido_2541819/

Gil, R. (2020a, May 20). Sánchez saca adelante la quinta prórroga del estado de alarma con fisuras en el bloque de la investidura. RTVE. https://www.rtve.es/noticias/20200520/votaciones-quinta-prorrogaestado-alarma-coronavirus/2014443.shtml

Gil, R. (2020b, June 3). El Congreso aprueba la sexta y última prórroga del estado de alarma en un bronco pleno marcado por Marlaska. RTVE. https://www.rtve.es/noticias/20200603/congreso-aprueba-sextaultima-prorroga-del-estado-alarma-bronco-pleno-marcado-marlaska/2015448.shtml

Guasti, P., \& Mansfeldova, Z. (2016). Parliamentary Opposition in Times of Change and Crisis: The Case of Czech Republic. ECPR General Conference: Opposition Parties in European Legislatures under Pressure. https://ecpr.eu/Events/Event/PaperDetails/28745

Jenny, M., \& Muller, W.C. (2020). Parlamentarische Opposition in Der Corona-Krise. Austrian Corona Panel Project - Corona-Blog. https://viecer.univie.ac.at/corona-blog/corona-blog-beitraege/blog38/

Jiménez, F. (2020, April). The Political Management of the COVID-19 Crisis in Spain. Fondation Robert Schuman. https://www.robert-schuman.eu/en/doc/divers/Covid-19_Spain.pdf

Jones, S. (2020a, Jan. 7). Socialists and Podemos to rule together in Spanish coalition. The Guardian. https:// www.theguardian.com/world/2020/jan/07/pedro-sanchez-spain-pm-government-vote-parliament

Jones, S. (2020b, June 21). No enemy but the virus? Why Spain's opposition is rounding on the government. The Guardian. https://www.theguardian.com/world/2020/jun/21/no-enemy-but-the-virus-why-spainsopposition-is-rounding-on-the-government

Katz, R.S., \& Maier, P. (1995). Changing Models of Party Organization and Party Democracy: The Emergence of the Cartel Party. Party Politics, 1(1), 5-28.

La Moncloa. (2020, June 21). Estado do Alarma. https://www.lamoncloa.gob.es/covid-19/Paginas/estadode-alarma.aspx

Łabędź, K. (2012). Opozycja parlamentarna jako przedmiot badan. In K. Łabędź (Eds.), Opozycja parlamentarna $w$ Polsce w latach 1997-2010 (pp.9-26). Wydawnictwo Naukowe Uniwersytetu Pedagogicznego.

Lamet, J. (2020, May 6). El PP se abstiene en la votación de la prórroga del estado de alarma entre críticas al "absolutism" de Pedro Sánchez. El Mundo. https://www.elmundo.es/espana/2020/05/06/5eb280d0 fc6c838a508b463e.html

Lamet, J. (2020a, March 20). Pablo Casado lanza "una reivindicación desesperada” para exigir más material sanitario y "tests masivos". El Mundo. https://www.elmundo.es/espana/2020/03/20/5e74dd55f21efa03 2068b45ac.html

López, O. (2018). Del 15M al Procés: La Gran Transformación de La Política Española. Editorial Planeta.

Manetto, F., \& García de Blas, E. (2016, May 16). Unidos Podemos, el nombre de la coalición de Podemos e IU.El País. https://elpais.com/politica/2016/05/13/actualidad/1463124909_878642.html

Marcos, J. (2016a, May 19). El 87,8\% de los españoles cree que los partidos deben apoyar al Gobierno y dejar las críticas para más adelante, según el CIS. El País. https:/elpais.com/espana/2020-04-15/ el-878-de-los-espanoles-creen-que-los-partidos-deben-apoyar-al-gobierno-y-dejar-las-criticas-paramas-adelante-segun-el-cis.html

Marcos, J. (2016b, May 19). El 75\% de los españoles cree que no es el momento de que la oposición lance críticas contra la gestión del Gobierno. El País. https://elpais.com/espana/politica/2020-05-19/el-apoyo- 
al-gobierno-por-la-gestion-de-la-crisis-del-coronavirus-se-resiente-pero-sigue-en-el-75-segun-el-cis. html

Mayor, L. (2020, April 22). El Congreso aprueba la tercera prórroga del confinamiento con una oposición mucho más crítica. La Vanguardia. https://www.lavanguardia.com/politica/20200422/48679643891/ congreso-aprueba-tercera-prorroga-estado-alarma.html

Minder, R. (2019, September 17). Spain Heads to $4^{\text {th }}$ Election in 4 Years After Failure to Form Government. The New York Times. https://www.nytimes.com/2019/09/17/world/europe/spain-election-governmentcollapse.html

Mueller, J.E. (1973). War, Presidents, and Public Opinion. Wiley.

Orriols, L., \& Cordero, G. (2016). The Breakdown of the Spanish Two-Party System: The Upsurge of Podemos and Ciudadanos in the 2015 General Election. South European Society and Politics, 21(4), 469-492. DOI: $10.1080 / 13608746.2016 .1198454$.

Palau,A., Muñoz, L., and Chaqués-Bonafont, L. (2015). Government-Opposition Dynamics in Spain under the Pressure of Economic Collapse and the Debt Crisis. The Journal of Legislative Studies, 21(1), 75-95. DOI: 10.1080/13572334.2014.939565.

Pastuszko, G. (2018). Wpływ opozycji parlamentarnej na funkcjonowanie naczelnych organów władzy państwowej. Wydawnictwo Adam Marszałek.

Pinedo, E., Melander, I., Luelmo, P., and Faus, J. (2020, April 2). How the coronavirus spread in Spain. Reuters. https://www.reuters.com/article/health-coronavirus-spain-factbox-idUSL8N2BO4TL.

Xis, S., \& Noury, A. (2016). Government-Opposition or Left-Right? The Institutional Determinants of Voting in Legislatures. Political Science Research and Methods, 4(2), 249-273. DOI: 10.1017/psrm.2015.9. 